\title{
Structuralism Approach: Symbolism Of Traditional Batik Pattern Of Javanese Traditional Clothes In Surakarta
}

\author{
Sarwono \\ Study Program of Textile Craft, Faculty of Visual Art and Design \\ Sebelas Maret University
}

\author{
Edi Kurniadi \\ Faculty of Teacher Training and Education, Sebelas Maret \\ University
}

\begin{abstract}
Paradigm model of Structuralism-Symbolism of Traditional batik pattern in Surakarta, a method which analyzes the Javanese thinking and paradigm. The method used in this research is the structuralism approach. Realism is proposed to see the "surface structure" and "deep structure" which was convinced, but they were not enough to touch the deepest understanding because they live in the social community of people Javanese.
\end{abstract}

Keywords: Structuralism, Symbolism, Traditional Batik Pattern.

\section{INTRODUCTION}

After Many approach appears in many studies based on the need in analyzing problems and mean which every approach has its own argumentation and opinion.one of these approach is" structuralism". Structuralism is one of social anthropologic approaches. According to Levi- Strauss, this approach have to emphasize an inductive factor in analyzing the structures of society. This approach basically gained from social structure which is exist in the society, therefore this studies could only be analyzed through empirical data collecting (Ahimsa, 2002).

This Levi-Strauss's model analysis is implemented toward object studies in this paper, that is a studies about Symbolism of Traditional Batik Pattern in Javanese Traditional Clothes of Surakarta. So, the structuralism in this paper will be directed into a symbolism analysis studies. This paper concern about values which are contained in traditional Batik pattern of Javanese traditional clothes. These values are gained from ideas, passion, beliefs, principal, experiences, certain abstraction, creative process and production process which are existing in Javanese society. This symbolism studies which is concerned to Traditional Batik Pattern of Javanese Traditional Clothes in Surakarta, is employed for the purpose to study the exiting social structure which is developing in the Javanese's society's imagination. This structure is felt and understood as a reality in society, but it is invisible. This condition is what Levi-Strauss called as "deep structure' Deep structure is certain competition which its construction is based on the surface structure expressed and existed in reality (Kaplan, 2000).

Before discussing for further analysis, bellow is the distribution of the structure. There are three kinds of structural distribution: wholeness, transformation and self-regulation. Wholeness is a structure which is related to construction, that is a body which is binding the material data systematically and systemic. Transformation is an ability of binding element in the structure to transfer or transform to another shapes, or delection and addition probably happen based on the transformation values in its mechanism. The elements are static but rather dynamic. This condition is not a factor that influencing the structure, therefore the transformation become an apparent thing, change and develop in society. The third stage is self-regulation which is an idea in making a defensive structure. A stage of life in which human or social system in defensing their life. This reality is related to the perception function by Emil Durkheim in Social Science that is a method in anloging the social institution with another organism. Organism term shows the symbiosis or relativity among the entities. Within this interaction, entities form a structure which is explained by Levi- Strauss as a system or a model (Ahimsa, 2001).

The three distribution of structure have covered the existence of spiritual structure and concept of physical structure. In observing the form in depth, we have to do an empirical study and emphasize a participative observation. This approach is characterized by social interaction between the observer and the environment of the subject. Within this process, data in the form of field note are collected systematically and are employed in interactive analysis (Sutopo, 2002). This approach of social studies is aimed as a studies which is based on grounded theory, in which data are able to be processed and analyzed directly in the research field. (Muhajir, 2002).

\section{LITERATURE REVIEW}

\section{Traditional Batik Pattern as the Symbol of Javanese} Society' Characters.

Javanese culture cannot be separated from philosophical values both spiritual an physic. This rock Landasan inilah is often called "Kejawen" in many cultural studies in Javanese culture (Suseno, 2000). The principle point which is becoming the ground of kejawen is called ngilmu, thus, Javanese values could transform narrow space to universal space (Holt, 2000). Even though these values are existing in certain and narrow space that is Java, but the culture itself goes beyond human life. The truth and perfection containing in philosophical Javanese culture are reflected in the 
symbolism values appeared due to the interaction between human and the micro- macro cosmos, between spiritual life and physical life.

If we look deeper into Javanese culture particularly the spiritual element, there are efforts for human to be a pure and firtous mankind in their attitude both thinking and action. These virtuous and pure attitude have a close relationship with spiritual and physical life. These values appear due to the relationship among human and between human and God. This relationship is universal, because human cannot be separated with nature and its law and also with the Almighty God. That way the existing principle have to be noticed particularly power of nature principle, humanity principle, nationality principle, freedom principle and cultural principle. With the understanding of the power of nature, it is hoped that human have to fulfill all their needs both spiritual and physical need. It can be seen clearly that is Javanese culture there are a balance between human's heart and nature and also the Almighty God. Human's heart and intellectuality have a close relationship with the almighty God. The relationship is trying to teach a value that human have to find a balance between their attitude and nature and also have to find a perfection of life (Mulder, 1996).

Structural approach in a studies is a way to look for connections which will reveal meaning and symbolism in the systemic means. Traditional Batik pattern will be meaningful if we could find out connections in their structure, because symbolism could define connections within Javanese people's characters and soul. The basic assumption is placing the structural understanding analogically with other organism which are existing in the society, therefore redeliffe brown defines structure as a set of hierarchy system of relationship in unity and wholeness.

\section{Symbolism And Traditional Batik Pattern In Javanese Traditional Clothes}

People often misguided in interpreting symbolism and symbol. This is caused by these two terms are translated as the same meaning that is a 'symbol'. Symbol is a visual shape of artist's description of ideas based on their deepest feeling. Thus, what containing within a symbol is values which are reflecting the deepest feeling of an artist. Since symbol is a direct description of ideas, there will be a heterogeneous characters within it, both spontaneous and logically. This mixture is not only based on rationality but also based on the deepest feeling and its manifestation. As the visual shape which is described directly from ideas and contained values of an artist, symbol is having unity characteristic. In art, symbol itself is drawed in art works (Langer, 1962).

Symbolism is symbols which are used in art and any other field to give certain mark to something by suggesting it through sense of intangible imaginations of the things. For the example, someone who is honored wearing classical batik fabric to show his quality, power and pride. According to read: symbolism could be in a form of art work which its supporting elements describe the analogy of values of certain characters. Values of these abstract ideas will form unity or gestalte of quality, power and pride (Read, 1970).

Traditional batik pattern in Javanese traditional clothes are containing and fulfilling all the above elements, because they were made in a unity of quality, power and pride at that time as an art work to legitimate status and prestige the kingdom as a ruler (Soedarmono, 1990).

Each of traditional batik pattern in Javanese traditional clothes was made based on symbolism within Javanese philosophies. The purpose of this creation was to bring wealth, peace, pride and honor and also social status.

Meaning, according to Umberto Eco is a mode of sign presenting cultural unity which is visualized by other signs in which it covers relations among referred object (Masinambow, Hidayat, 2001). Meanwhile, meaning in Levi-Strauss theory is an in depth study segmented in transformed structures. Structure will give an explanation about class, function and form of relations. This paper concerns in structuralism approach applied in a stable and narrow scope of cultural community that is Javanese people community in Surakarta. Robert Redfield called this system as "cultural otonom system", that is an independent community or a community which does not need supports from a complementary, reciprocal and subordinate second system.

The existence of Batik pattern in Javanese traditional clothes of Surakartanese is one of supporting elements for most of its people, both spiritual and social life. The function of traditional batik in Javanese traditional clothes in people's life is to sign certain events and as a mode to communicate socially and spiritually (Eric, 1983). This functional relation will give direction to observe the existence of "meaning" or "mean". According Levi-Strauss, mythology is a medium to zoom out or a magnifying glass and reflector that enable us to understand attitude and activities of the fundamental systems and its universality closely. This prior of the material structuring process is taken from reality and others myth medium remain (Cremers, 1997).

Those ideas are not included in relationship within creative process of classic artists, including process of leather puppet making process. This is caused by the absent of technical and choreography knowledge within classic art's making process and this process is mostly done within wild thought, therefore the creative process is held unconsciously. This unconscious mind will form a construction which will describe the structural relations. Moreover, Levi-Strauss explains that the mythology philosophers (including the artists in this case) will use ideas or concrete and empiric material, and perception such as destiny, dark-bright, blackwhite, etc. This understanding can be used to consider the synthesis to understand abstract ideas. The abstract ideas mostly think about connections of nature and culture and also others existence. Those empirical and concrete materials and the global perception do not have any competitor due to their otonom characteristic. Moreover, all the remaining concrete materials are formed and arranged in a structural context of an object, in this case is batik pattern in Javanese traditional clothes. Therefore, there will be relations within 
construction forming a structure, pattern and an outline in understanding problems, so it can reflect the universal conditions of the unconscious thinking process.

\section{RESEARCH METHOD}

With Paradigm model of Structuralism - Symbolism of Parang motifs in the Surakarta style, where that is one method seeing for people Java -nese thinking has been given support them. In the realism it was purposed for seeing again about "surface structure" and "deep structure".

This construction (structure, pattern, and design) enables the study and analysis of meaning and symbolism of parang pattern within traditional batik pattern in Javanese traditional clothes.

Such kind of systematic shows an inductive approach by using a holistic, wholeness and complex thinking. In understanding an object, we do not only observing the organic elements in the relation system, but also considering the outside elements which are containing significant context with the organic element. Thus, the holistic thinking can be used as an analysys method (Sutopo, 2002).

Discussion : Spiritual structur and Simbolism of Parang Pattern in Javanese Leather Puppet Costumes.

Complexity of life is often become problems in human life, therefore, the 19th century sociologist such as Augus Comte and H. Spencer made an analogy that the basic material of social life as if a simplest biological organism.(Kuntjaraningrat, 1987).

Moreover, this analogy developed into functional structural theory by Talkott Parson, K. Davis and Robert K. Morton. The main point of this theory is emphasizing on mechanical reality of system and it can be interpreted as a united component from the interacted elements in certain period of time and are based on certain pattern. The understanding of the problems show function of culture is not only as an outcome of interaction among people in a social institution, but also as a system which will form paradigm and attitude. In stage of material reality, there are various form, but in spiritual structure reality, it will show some symbolized of view and characters. As we can see in parang pattern in Javanese leather puppet costumes. Materially, it has various form, but spiritually, they were formed by symbolism of Javanese characters particularly Surakartanese customs.

As in poem or epic, batik pattern also do not have physical reality but intangible form as the result of collective thinking. The collective character shows that there are complexity of ideas which are hidden beyond symbolism, so it can be explained that symbolism of traditional batik patterns in Javanese traditional clothes are the reality of "super organic" symptom. Super organic symptom is a visualized reality within art, not only in a form of material but according to Suzanne K. Lenger it is also as a form of "Virtuality" Virtuality is something exist but cannot be touched, it only can be felt. This is what the so called "essence of imitation" or fundamental instinct within human destiny.
The usage of traditional batik pattern in Javanese traditional clothes are adjusted with the social status based on palace customs. For example, parang rusak barong pattern have to be worn by a King, parang kusuma pattern have to be worn by Knights and etc. Parang pattern has various form such as Parang kembang, Parang Curiga, Parang Klithik, Parang Ngesti, Parang Sarpa and etc. All of this patterns have a symbolic meaning and has different application toward Surakartanese leather puppet costumes.

Looking from its making and naming proces, parang pattern has certain concepts: Javanese people believe that the kings of Java Kingdoms will always become goddess in heaven, in reverse, the goddess may also reincarnate as Kings or knights. Thus, daily activities and habit of kings (including wearing Parang Barong pattern) are manifested toward goddess costumes in Javanese leather puppet characters. Javanese people believe that there are magical power hidden inside an object. They believe their ancestor are living inside the objects. Those magical power can be used by human for a good or evil purpose. Within Surakartanese leather puppet, the concept og magical power always get along with human's life. Believes toward magical power in an object can be seen in the making process of Batik Parang such as, Parang Curiga, Parng Kusuma, Parang Kembang etc. All of these pattern has hidden hope that is the magical power of the pattern itself, so the one who wear it will be able to achieve their will by wearing it.

Kawung pattern usually worn by the palace servants (servants whom close to king and his families). What is meant as servants here are lower class servant such as nanny, knight assistant, and palace court officers (Tumenggung). Batik Kawung can be divided as follow: Kawung Sari, Kawung Sekar Ageng, Kawung Sen, Kawung Picis, Kawung Beton, Kawung Semar, Kawung Buntal, Kawung Kembang, Kawung Seling. Meanwhile, Sidomukti, Sidomulyo, Sidoluhur and Sidoasih pattern are used by wedding couple both bride and groom. It is hoped that the couple will be blessed in their marriage and they are able to socialize with others.

Sidomukti pattern is commonly used in Javanese wedding ceremony, while the others pattern are rarely used. Sidomukti pattern is worn by wedding couple in "Pangeran"style, not " basahan" style. Basahan style using a long fabric called dodot with Semen Rama pattern.

Batik Truntum as one of clothing customs among Surakartanese is manifested in the visalization of Javanese people paradigm. Javanese people in making art work especially Batik, are not only considering material and aesthetic purposes but also considering the phylosophical aspect such as the humble toward the almighty God. This belief is existing among Javanese people as a part of their life. Besides, javanese people are like to make hidden phyloshophy and proverbs beyond the art works or cultural works, and it is rarely expressed explicitly.

Batik Truntum can be divided into: Truntum Polos, Truntum Lar, Truntum Seling Sidomukti, and Truntum Seling. Batik Truntum in Javanese wedding ceremony is worn by the couple's parents both man and woman. It is 
hoped that by wearing this batik, the parents are able to guide their son and daughter in their marriage life and guide them how to socialize with others after they are married.

Another pattern is Batik Ceplok. This pattern can be divided into: Ceplok Lung Slop, Satriyi Wibowo, Ceplok Sriwedari, Grompol, Cakar, Srinugroho, Wora Wari Rumpuk, Ceplok Sari Ngemboka, Bolu Rambat, Ceplok Candi Luhur, Ceplok Burba.

Batik Ceplok has a close relatioship with kejawen beliefs. Ground for these beliefs is the concept of nature's power instead of human's power. Batik ceplok symbolized that a king is a symbol of power in the world. King is a medium for God's mercy in the world, then the king should give the mercy to his people also. The king is also considered as a protector of the prevailed laws.

The power among human is understood as the power of king toward his people, inspired by ceplok pattern which has one center point in the middle of main ornament. Four elipses pattern in Batik Ceplok are the symbolism of people who always protect and be around the king. The other important pattern of traditional batik are ( the symbol of harmonisation of nature), this pattern doesn't follow the principle of geometric, this kind of motive is called batik "semenan". This semenan can be divided into Semen Rama, Semen Wijaya Kusuma, Gunung Lar, Bledag, Sekar Jagad, Ukel, Cuwini, Wahyu Tumurun, Semen Prabu, Semen Gendhong, Semen Nagaraja, Babon Angrem and etc.

The third important batik patterns is "boketan". This pattern is made arbitrary according to the maker sense of art, therefore the patterns are not the same for each fabric.

The symbolic meaning contained within traditional batik which is used in Javanese people in Surakarta, as expressed in batik Parang, Kawung Ceplok, Sidomukti, Sido luhur, Sidomulyo, Wahyu Tumurun, Semen Rama, Wijaya Kusuma and etc., are suitable with Javanese customs in Surakarta. Symbolism within batik pattern containing the philosophies of Javanese culture. The application of yellow, white, red, blue, black characterized of Javanese people. The colors have symbolism of cosmology or what the so called "keblat papat lima pancer" in Javanese term. Each wind direction has its own symbolic color. East = black, South $=$ red, West $=$ yellow and North $=$ white. The remain color is the mixture of these four color and called as "lima pancer" meanwhile, according to Javanese magical beliefs, these five colors are the symbols of earth $=$ black, fire $=$ red, win $=$ yellow, water $=$ white and human which are symbolized with various colors. These beliefs are aimed to look deeper into spiritual structure and deep structure which cannot be touched or seen. But these beliefs are existing among Javanese people.

Physical structure is a result of observation which technically can be transformed into note of parang meaning and its application within Javanese traditional clothes in Surakarta. Meanwhile, spiritual structure is a result of study of mindset and paradigm of Surakartanese. If these structures are existing. Therefore, these structures will guide all the pattern, attitude and motive of artists' creativity. The spiritual structure becomes the last aim to explain mindset and paradigm of the unconscious mind of Javanese people which support the creation of art works. Thus, the meaning of structuralism as an approach is lying upon its efforts to describe the object symbolically/. It means that systemic study is able to shows the meaning of batik pattern within Javanese traditional clothes in Surakartas.

\section{CONCLUSION}

Based on the discussion above, it can be concluded several points as follow:

The background of batik art in Javanese ceremonial tools particularly in Surakarta, was the same as common Javanese ceremony suitable with the Batik pattern itself. There were various kind and usage of batik pattern, they are:

It is unknown how batik painting become widely spread in Indonesia. The development of batik inside the palace was occures in line with the development outside the palace. Palace has the media, and the experts of batik, therefore, batik painting inside of palace is better and dominant that batik painting outside the palace.

The first category is batik pattern with geometric distribution pattern, such as Parang, Kawung, Ceplok, Sidomukti, Sidoluhur, Sidomulyo, Sidaasih pattern. The second category is the pattern in which its main ornament consist of plants and animals pattern (meru, lar laran) which are arranged in well harmony and composition, but ignoring geometric rules, thus, it is called "semenan" pattern. This pattern includes Semen Rama, Semen Wijaya Kusuma, Gunung Lar, Bledag, Sekar Jagad, Ukel, Cuwiri, Wahyu tumurun, Grinsing, Semen Prabu, Semen Gendhong, Semen Nagaraja, Babon Angrem and etc.

The third category is "boketan" batik pattern, where the pattern are made arbitrary according to the maker taste and sense of art. Therefore, this pattern has different ornament in each fabric.

A symbolic meaning contained within traditional batik pattern in Javanese ceremony particularly in Surakarta, as explained in Parang, Kawung, Ceplok, Sidomukti, Sidoluhur, Sidomulyo, Wahyu Tumurun, Semen Rama, Wijaya Kusuma and etc, have a symbolism suitable with the usage of the pattern itself within Javanese ceremony in Surakarta. The true symbolism of the pattern is lay upon Javanese philosophical values itself which is shaped based on religio-magical outline. The usage of yellow, white, red, blue, and black colors become the characters of Javanese people who are worshiping "causa prima", and also as the symbol of cosmological characters called "keblat papat lima pancer" each wind direction has a symbolic color, East = black, south $=$ red, West $=$ yellow and north $=$ white. The remaining color is the mixture of these four color and called as "lima pancer". Meanwhile, according to Javanese magical beliefs, these five colors are symbols of earth $=$ black, fire $=$ red, wind $=$ yellow, water $=$ white and human which are symbolized with various colors. Bangun tulak colors are the dark colors symbolizing thoughtfulness. The bride 
(in siraman ceremony) wear nyamping kemben fabric with "bangun tulak" colors, with the composition of blue black with white pattern. This kind of batik pattern has a symbolism to put the evil spirit away from the bride and bring the ancestor nearer to protect her, in order to make her marriage happy and far from danger.

A Structuralism - Symbolism model in studying traditional batik patter within Javanese traditional clothes particularly in Surakarta is a method to find the existence of Javanese people paradism pattern through mentality structure, so this structure is a form of established construction in this study. This understanding is aimed to show the facts which after a long time have been unconsciously become part of Javanese people reality. This sight is giving a new consideration and analysis and also opening new understanding toward the efforts of the people, the scholar and the artists in facing a complex dynamic development within their community.

\section{ACKNOWLEDGEMENT}

First and foremost a special thanks to those involved in this research especially Universiti Putra Malaysia. Further, those individuals who contributed and involved in the discussion for this research, among others are $\mathrm{Mr}$ Fadly Sabran from UiTM Seri Iskandar Perak, Mr Fariz Hanapiah from Motiofixo, Mr Syafiq Samad from UiTM Merbok Kedah and Mr Sufri Jay, Young Contemporary Award Finalist 2013. Finally, our utmost gratitude to all the people who have supported us directly or indirectly throughout this research.

\section{REFERENCES}

[1] Ahimsa-Putra., H.S,2002, "Tanda Simbol Budaya dan Ilmu Budaya", Makalah,Yogjakarta: Unit Pengkajian dan Pengembangan Budaya.

[2] Ahimsa- Putra, H.S, 2001, Strukturalisme LeviStrouss, Yogjakarta: Galang Press

[3] Cremmer., A, 1997, Antara Alam dan Mitos, Flores: Nusa Indah

[4] Erik, R.W.,1983, Petani Suatu tinjauan Antropologis, (terjemahan): Tim yayasan Ilmullmu Sosial, Bandung : Rajawali

[5] Holt , C., 200, Melacak Jejak Perkembangan Seni Di Indonesia, (terjemahan): Soedarsono, Bandung: Arti line

[6] Kaplan, D., Manners, A.A, 2000, Teori Budaya, (terjemahan): Landung Simatumpang, Jogjakarta: Pustaka Fajar.

[7] Koentjoroningrat, 1987, Sejarah Teori Antropologi I, Jakarta: Universitas Indonesia Press

[8] Langer, S.K., 1962, Expressivenes and Simbilis: london

[9] Masinambow, E.K.M., Hidayat, S., 2001, Semiotik, Jakarta: Balai Pustaka.

[10] Muhajir, N., 2002, Metodologi Penelitian Kualitatif, Yogjakarta: Rake Sarasin

[11] Mulder, N., 1996, Kepribadian Dan Masyarakat di Jawa, Jakarta: Pustaka Sinar Harapan

[12] Read , H., 1970, Education Trough Art, London: University of California Press.

[13] Soedarmono , 1990, Dinamika Kultural Batik Klasik Jawa, Sarasean Kebudayaan, Surakarta:
Taman Budaya Jawa Tengah.

[14] Susena, F.M., 2001, Etika Jawa, Jakarta: P.T. Gramedia Pustaka Utama.

[15] Sutopo , H.B., 2002, Metodologi Penelitian Kwalitatif, Surakarta: Universitas Sebelas Maret Press.Parks, John A., (2015). Universal Principle of Art. 100 Keys for Understanding, Analyzing, and Practicing Art. Beverly, Massachusetts, USA. Rockpoty Publishers. 